\title{
Immune Responses to Strenuous Exercise and Carbohydrate Intake in Boys and Men
}

\author{
BRIAN W. TIMMONS, MARK A. TARNOPOLSKY, AND ODED BAR-OR \\ Children's Exercise and Nutrition Centre [B.W.T., O.B.-O.], Departments of Pediatrics and Medicine \\ [M.A.T.], McMaster University, Hamilton, Ontario, Canada, L8N $3 Z 5$
}

\begin{tabular}{|c|c|}
\hline \multicolumn{2}{|c|}{ ABSTRACT } \\
\hline 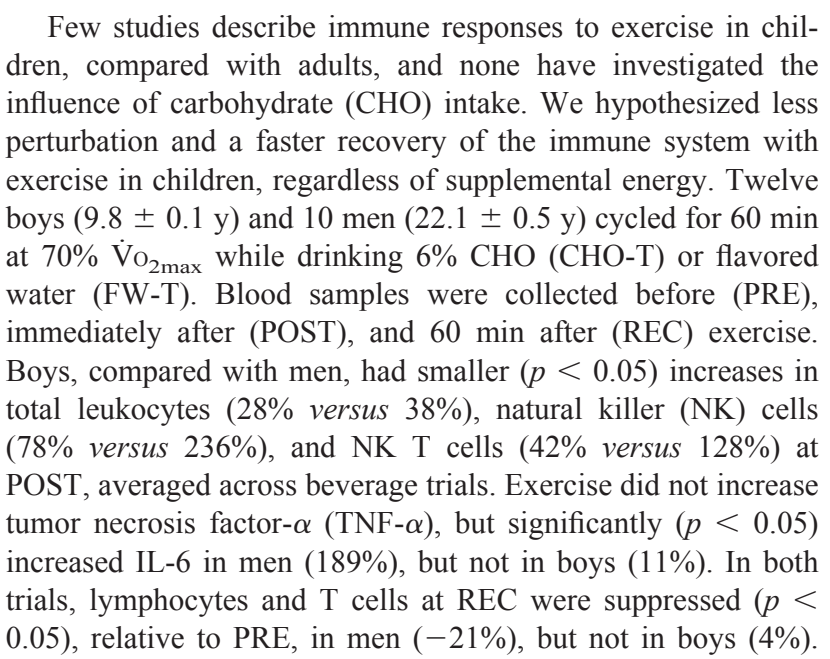 & $\begin{array}{l}\text { IL-6 remained elevated }(p<0.001) \text { in men at REC, with no } \\
\text { change from POST in boys. In boys, but not in men, CHO } \\
\text { significantly }(p<0.05) \text { attenuated increases in neutrophil, lym- } \\
\text { phocyte, and NK cell counts at POST. Neutrophils at REC in } \\
\text { CHO-T were lower }(p<0.05) \text { than in FW-T in men }(\sim 25 \%) \text { and } \\
\text { in boys }(\sim 17 \%) \text {. CHO had no effect on TNF- } \alpha \text { or IL-6 in either } \\
\text { group. Our results indicate a distinct pattern of the immune } \\
\text { response to exercise and CHO intake in boys, compared with } \\
\text { men. (Pediatr Res 56: 227-234, 2004) } \\
\text { CBC, complete blood count } \\
\text { CHO, carbohydrate } \\
\text { IL-6, interleukin-6 } \\
\text { NK cells, natural killer cells } \\
\text { TNF- } \alpha \text {, tumor necrosis factor- } \alpha \\
\text { Vo } \mathbf{o}_{\mathbf{2}} \text {, oxygen consumption }\end{array}$ \\
\hline
\end{tabular}

Strenuous exercise can significantly influence several elements of the human immune system. The magnitude and direction of changes in immune cell counts, for example, are mediated by the intensity of the activity $(1,2)$, the nutritional status of the subject $(3,4)$, and changes in stress hormones, in particular epinephrine during exercise (5) and cortisol after exercise (6). Although most immune cells increase in concentration during exercise, a brief period of immunosuppression, termed the "open window," occurs during recovery from strenuous exercise and may increase susceptibility to infection (7). Another component of the immune system response to exercise is cytokines. Cytokines serve in a network to help regulate signaling of innate and specific immune responses (8). Traditionally, cytokine responses to exercise, in particular IL-6 and TNF- $\alpha$, have been interpreted in the context of immune-

Received October 6, 2003; accepted March 2, 2004.

Correspondence: Oded Bar-Or, M.D., Children's Exercise and Nutrition Centre, Chedoke Hospital, Evel Bldg. ( $4^{\text {th }}$ floor), Sanatorium Road, Hamilton, ON, Canada, L8N 3Z5; e-mail: baror@mcmaster.ca

Supported, in part, by the Natural Sciences and Engineering Research Council of Canada and the Gatorade Sports Science Institute. B.W.T. is a recipient of an NSERC Industrial Scholarship sponsored by the GSSI.

DOI: 10.1203/01.PDR.0000132852.29770.C5 mediated host defense (9). However, exercise-induced increases in plasma levels of IL- 6 and TNF- $\alpha$ are not always associated with simultaneous increases in their intracellular production or excretion from immune cells $(10-13)$. Therefore, changes in these low-molecular-weight proteins with exercise likely serve roles in addition to their control of inflammation.

It is important to note, however, that our current understanding of exercise-induced changes in components of the human immune system is derived primarily from adults, and there is a paucity of data on children. With respect to immune cell counts, a few studies have reported similar responses to aerobic exercise between children and adults (14-16). However, these studies did not make direct comparisons between children and adults under identical, experimental conditions, and closer inspection of the data (14-16) would suggest that the magnitude of change in various immune cells was smaller in younger subjects, compared with older ones. However, convincing proof of age-related differences in the immune response to prolonged exercise is lacking. In addition, we are aware of no study that has directly compared the inflammatory cytokine response to exercise between young children and adults, but 
limited evidence suggests that muscle damage associated with exercise, which produces an inflammatory response, may be less in children than in adults $(17,18)$. Moreover, to our knowledge, no study has directly compared the recovery of immune cells or cytokines after exercise in children with that in adults. Considering that children tend to have a faster physiologic (e.g. heart rate and ventilation) recovery from exercise than do adults (19), immune cells may also recover more quickly in children than in adults, thereby limiting the "open window" period.

Recently, there has been growing interest in nutritional strategies to modify the immune response to acute exercise in adults (reviewed in ref. 20). For example, compared with water, $\mathrm{CHO}$ ingestion during exercise can attenuate the expected increase in neutrophils $(21,22)$, mononuclear cells $(23$, $24)$, and several inflammatory cytokines (25-28). Furthermore, the postexercise recovery of immune cells tends to be faster with the ingestion of $\mathrm{CHO}$, compared with water $(21,23,24)$, which may reduce the "open window" period. CHO-induced attenuation of leukocyte trafficking is likely due to a blunted stress hormone (e.g. epinephrine and cortisol) response mediated by maintained blood glucose concentrations (29). CHOmediated changes in cytokine levels indicate a reduced inflammatory response. Although debatable, some indirect evidence (30) suggests that the epinephrine response to sustained exercise may be smaller in children than in adults and, as discussed above, children may also have a smaller inflammatory response to a given amount of exercise. Therefore, the potential benefits of $\mathrm{CHO}$ ingestion on immune changes in children may be limited due to an already blunted stress hormone and an inherently smaller inflammatory response. However, no study has investigated the effects of $\mathrm{CHO}$ ingestion during exercise on immune changes in young (i.e. pre- and early pubertal) children to address this issue.

A clearer comprehension of the acute effects of exercise on the developing immune system may have important clinical implications for children with, or recovering from, an immunerelated disease. Therefore, the objectives of the present study were to determine possible age-associated differences in 1) the acute immune response to exercise, 2) the recovery of leukocytes and cytokines after exercise, and 3) the effects of $\mathrm{CHO}$ ingestion on the immune response to exercise. To address our objectives, we used a model of high-intensity exercise to produce significant perturbations in commonly reported aspects of the cellular immune system, including NK cells, which are the most responsive immune cell to exercise (6), and two commonly reported inflammatory cytokines, IL- 6 and TNF- $\alpha$. We hypothesized that in boys, compared with men, exerciseinduced changes in these elements of the immune system would be smaller, recovery of immune changes would be faster, and $\mathrm{CHO}$ ingestion would have a minimal effect on immune changes.

\section{METHODS}

Subjects. Twelve boys and 10 men volunteered for this study approved by the McMaster University Research Ethics Review Board. Table 1 summarizes their physical and fitness
Table 1. Subject characteristics

\begin{tabular}{lcc}
\hline & Boys $(n=12)$ & Men $(n=10)$ \\
\hline Age $(\mathrm{y})$ & $9.8 \pm 0.1$ & $22.1 \pm 0.5^{*}$ \\
Height $(\mathrm{m})$ & $1.42 \pm 0.03$ & $1.77 \pm 0.02^{*}$ \\
Body weight $(\mathrm{kg})$ & $35.1 \pm 1.8$ & $82.6 \pm 2.0^{*}$ \\
Body fat $(\%)$ & $15.9 \pm 1.7$ & $16.9 \pm 1.1$ \\
$\dot{\mathrm{V}}_{2 \text { max }}(\mathrm{mL} / \mathrm{kg} / \mathrm{min})$ & $45.2 \pm 1.2$ & $43.8 \pm 1.6$ \\
$\mathrm{HR}_{\text {max }}(\mathrm{beat} / \mathrm{min})$ & $197 \pm 2$ & $194 \pm 3$ \\
\hline
\end{tabular}

Values are means $\pm \mathrm{SEM}$. $\dot{\mathrm{V}}_{\mathrm{O}_{\max }}$, maximal $\mathrm{O}_{2}$ uptake; $\mathrm{HR}_{\max }$, maximal heart rate.

* Significant difference between boys and men, $p<0.05$.

characteristics. All subjects were healthy with no history of allergies and were not taking any medication. To determine pubertal status of the boys, a parent and the child assessed pubic hair development according to Tanner (31). Boys were either Tanner stage $1(n=8)$ or $2(n=4)$. After the purpose, procedures, and risks of the study were explained, written informed consent was obtained from the men. The boys agreed verbally to participate and their parent then signed a written informed consent.

Preliminary session. An initial visit was conducted $1 \mathrm{wk}$ before the experimental trials to measure body height (Harpenden Stadiometer, CMS Weighing Equipment Ltd., London, UK), body weight (BW; BWB-800, Tanita, Tokyo, Japan), and percent body fat (bio-electric impedance-101A, RJL Systems, Clinton Twp., MI, U.S.A.) of each subject. To determine $\dot{\mathrm{V}}_{\mathrm{O}_{2 \max }}$, a maximal exercise test was conducted, as previously described (19), on a mechanically braked cycle ergometer (Fleisch-Metabo, Geneva, Switzerland). Measurements of $\dot{\mathrm{V}}_{2}$ and $\mathrm{CO}_{2}$ production were made continuously using a metabolic cart (Vmax29, SensorMedics, Yorba Linda, CA, U.S.A.). A Polar heart rate (HR) monitor (Vantage XL, Polar Electro, Lake Success, NY, U.S.A.) was used to record HR throughout the test.

Experimental sessions. To account for the confounding effects of diet on immune responses to exercise $(3,4)$, subjects were asked to record their nutrient intake the day before their first trial. Physical activity was also recorded during this 24-h period, and strenuous activity was avoided by all subjects. Recorded food intake and activity were then repeated the day before their next visit. Two experimental trials were conducted $1-2$ wk apart. Upon arrival to the laboratory $(\sim 0730 \mathrm{~h})$, subjects consumed a small standardized breakfast (toast and sugar-free jam, $\sim 2.4 \mathrm{kcal} / \mathrm{kg}$; water, $\sim 3.4 \mathrm{~mL} / \mathrm{kg}$ ). Fluid intake for the session was calculated from a naked body weight taken after subjects finished their breakfast and emptied their bladder. Subjects then rested $(\sim 20 \mathrm{~min})$ before a pre-exercise blood sample was drawn from an arm or hand vein by venipuncture. Thirty minutes before the start of exercise, they were given their first drink $(4 \mathrm{~mL} / \mathrm{kg})$. The same volume was consumed every 15 min until the end of exercise and every 20 min during the first $60 \mathrm{~min}$ of recovery. We chose this drinking schedule as it has been used in previous adult studies investigating the effects of $\mathrm{CHO}$ ingestion on immune responses (22). Subjects cycled at a power output equivalent to $70 \%$ of their predetermined $\dot{\mathrm{V}}_{2 \max }$ for two 30 -min bouts separated by a 5-min rest period. Exercise began $30 \mathrm{~min}$ after the first blood 
sample and the target intensity was achieved within the first 5 min by analysis of expired gas. Before, during, and after exercise, each subject consumed either a $6 \%$ CHO-electrolyte solution ( $4 \%$ sucrose, $2 \%$ glucose, $\sim 18 \mathrm{mM} \mathrm{Na}^{+}, \sim 3 \mathrm{mM} \mathrm{K}^{+}$) or water (identical in flavor, sweetness, and electrolyte concentration, but without $\mathrm{CHO}$ ) for a total of $40 \mathrm{~mL} / \mathrm{kg} \mathrm{BW}$. Additional expired gas samples were collected at steady state from minutes $12-15$ and $27-30$ of each exercise bout. Immediately after exercise, a second blood sample was drawn within $30 \mathrm{~s}$ while subjects remained seated on the cycle ergometer. HR was monitored throughout the session. Subjects remained seated in the laboratory for $60 \mathrm{~min}$ after exercise, but were allowed to empty their bladder if necessary. At the end of the 60-min recovery period, a final blood sample was drawn. Except for $\mathrm{CHO}$ intake before, during, and after exercise, the $\mathrm{CHO}(\mathrm{CHO}-\mathrm{T})$ and flavored water (FW-T) trials were identical and performed in a counterbalanced order, with subjects blinded to the contents of their drink.

Glucose analysis. Whole blood $(2 \mathrm{~mL})$ treated with EDTA was centrifuged at $2000 \mathrm{~g}$ for $10 \mathrm{~min}$ and the plasma was stored at $-70^{\circ} \mathrm{C}$ until analyzed. Plasma glucose was measured enzymatically (2300L STAT, YSI Inc., Yellow Springs, OH, U.S.A.), and concentrations were corrected for exerciseinduced changes in plasma volume according to Dill and Costill (32).

CBC and immunophenotyping. Whole blood $(2 \mathrm{~mL})$ treated with EDTA was analyzed for total leukocytes, neutrophils, lymphocytes, monocytes, $\mathrm{Hb}$, and hematocrit with an automated Coulter counter by the clinical hematology group at McMaster University. An additional $2 \mathrm{~mL}$ of EDTA-treated whole blood was used to determine lymphocyte subsets. Ten microliters of MAb, directly conjugated with FITC (AntiCD3) or phycoerythrin (anti-CD16/CD56), were mixed with $100 \mu \mathrm{L}$ of blood and used to numerate total $\mathrm{T}$ cells $\left(\mathrm{CD}^{+}\right)$, NK cells $\left(\mathrm{CD}^{-} \mathrm{CD} 16^{+} \mathrm{CD} 56^{+}\right)$, and $\mathrm{NK} \mathrm{T}$ cells $\left(\mathrm{CD} 3{ }^{+} \mathrm{CD} 16^{+} \mathrm{CD} 56^{+}\right)$. All reagents were purchased from BD Biosciences (San Jose, CA, U.S.A.) and samples were stained as per the manufacturer's instructions within $6 \mathrm{~h}$ of collection. Briefly, mixed samples were vortexed and incubated for $20 \mathrm{~min}$ at room temperature (RT) in the dark. After adding $2 \mathrm{~mL}$ of FACSLysing solution to lyse red blood cells, samples were vortexed and incubated a further $10 \mathrm{~min}$ at RT. Samples were centrifuged ( $300 \mathrm{~g}$ for $5 \mathrm{~min}$ at RT), washed with $2 \mathrm{~mL}$ PBS (PBS) containing $0.1 \% \mathrm{Na}$ azide, centrifuged (200 $g$ for $5 \mathrm{~min}$ at RT), and fixed with $0.5 \mathrm{~mL}$ PBS ( $1 \%$ paraformaldehyde). Samples were stored at $3{ }^{\circ} \mathrm{C}$ for no more than $48 \mathrm{~h}$ before analysis by a FACScan flow cytometer and CELLQuest software (BD Biosciences). The lymphocyte population was gated using forward-scatter versus side-scatter characteristics and 10,000 events were counted per sample. Cell concentrations of each lymphocyte subset were calculated by multiplying the percentage of cells with appropriate fluorescence, with the absolute number of lymphocytes obtained from the CBC. Whole blood cell concentrations were corrected for exercise-induced changes in blood volume according to Dill and Costill (32).

Cytokine analysis. Whole blood $(2 \mathrm{~mL})$ treated with EDTA was centrifuged at $2000 \mathrm{~g}$ for $10 \mathrm{~min}$ and the plasma was stored at $-70^{\circ} \mathrm{C}$ until analyzed. IL- 6 and TNF- $\alpha$ were determined in duplicate with ELISA kits purchased from Endogen Corporation (Woburn, MA, U.S.A.). The sensitivity of these kits, as reported by the manufacturer is $<1 \mathrm{pg} / \mathrm{mL}$ for IL- 6 and $<2$ $\mathrm{pg} / \mathrm{mL}$ for TNF- $\alpha$. In our experience, some samples from the boys ( 9 of 54 for IL- 6 and 4 of 54 for TNF- $\alpha$ ) and from the men ( 7 of 54 for IL- 6 and 10 of 54 for TNF- $\alpha$ ) were below the detection level of the respective kit and were, therefore, set to the lowest positive number on the standard curve derived from the plate on which the sample was determined. The intra-assay coefficient of variation (CV) averaged $11.2 \%$ (range, 0.25-29\%) for IL-6 and 5.5\% (range, 0.16-26.3\%) for TNF- $\alpha$. The inter-assay CV for both cytokines averaged $6.5 \%$ (range, $0.22-14.9 \%$ ). All concentrations were adjusted for exercise-induced changes in plasma volume (as above).

Statistical analyses. Data are presented as means \pm SEM. Group differences in physical and fitness characteristics were analyzed by independent $t$ tests. A three-way mixed-factorial ANOVA with one between-factor (group) and two withinfactors (trial and time) was used to analyze cardiorespiratory variables, glucose, and immune cell proportions and counts. IL- 6 and TNF- $\alpha$ concentrations were not normally distributed and, therefore, $\log$ transformed before submitted to a three-way mixed factorial ANOVA (as above). Graphical presentation of IL- 6 and TNF- $\alpha$ is based on concentrations before transformation. Where appropriate, a Tukey's HSD posthoc test for unequal sample size was used to determine significance among means. STATISTICA for Windows 5.0 (StatSoft, Tulsa, OK, U.S.A.) software was used for all analyses, with the threshold for statistical significance set at $p \leq 0.05$.

\section{RESULTS}

$\boldsymbol{H R}$ and $\dot{V}_{o_{2}}$. During exercise, HR, averaged across trials, was not different between boys (158 \pm 3 beats $/ \mathrm{min})$ and men $(157 \pm 4$ beats $/ \mathrm{min})$, representing $80.9 \pm 1.2 \%$ and $81.0 \pm$ $1.2 \%$ of maximal HR, respectively. The average HR for both groups was slightly, but significantly, lower $(p=0.02)$ during FW-T $(156 \pm 2$ beats/min) than CHO-T $(160 \pm 2$ beats/min $)$. To account for differences in body size, $\dot{\mathrm{V}}_{2}$ measured during exercise was expressed relative to BW (i.e. $\mathrm{mL} / \mathrm{kg} / \mathrm{min}$ ). Oxygen uptake was not different between boys and men $(p=$ 0.97 ) or between FW-T and CHO-T ( $p=0.64$ ), averaging 31.2 \pm 1.1 and $31.4 \pm 1.3 \mathrm{~mL} / \mathrm{kg} / \mathrm{min}$, respectively, in the boys and $32.1 \pm 1.0$ and $31.9 \pm 1.0 \mathrm{~mL} / \mathrm{kg} / \mathrm{min}$, respectively, in the men. When $\dot{\mathrm{V}}_{2}$, averaged across trials, was expressed as a percentage of $\dot{\mathrm{V}}_{\mathrm{O}_{\text {max }}}$, boys $(69.3 \pm 1.5 \%)$ had a slightly lower $(p=0.01)$ value than men $(73.3 \pm 1.0 \%)$.

Plasma glucose. Plasma glucose concentration [glucose] at rest (Fig. 1), averaged across trials, was slightly, but not significantly, lower $(p=0.07)$ in the boys than in the men. Compared with CHO-T, postexercise plasma [glucose] in both boys and men was lower $(p<0.001)$ in FW-T. Plasma [glucose] immediately after and $60 \mathrm{~min}$ after exercise was not significantly different between groups in either trial.

$\boldsymbol{C B C}$. Immediately after exercise, leukocyte counts were lower in boys than in men in both trials $(p<0.05)$, with no effect of $\mathrm{CHO}$ ingestion (Table 2). During recovery in FW-T, 


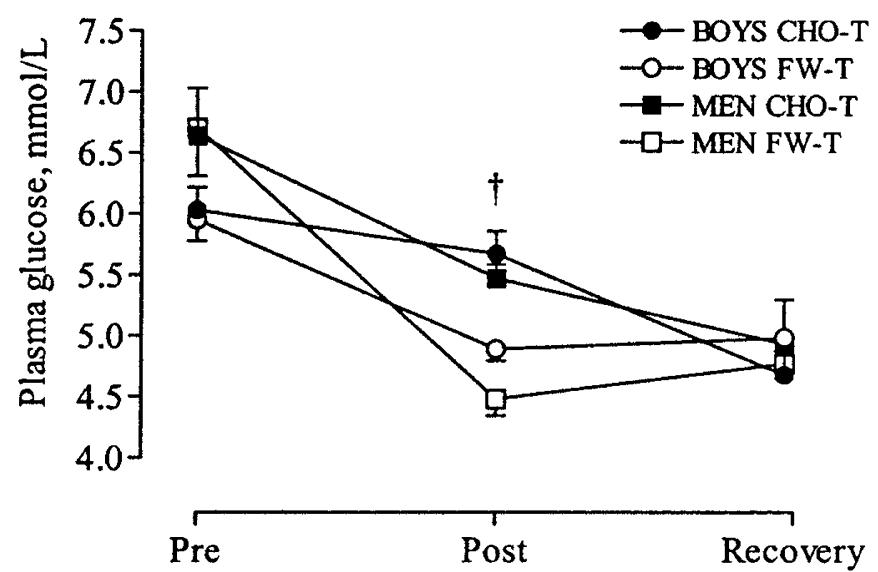

Figure 1. Plasma glucose concentration before, immediately after, and $1 \mathrm{~h}$ after exercise in flavored water and carbohydrate trials for boys and men. Values are mean \pm SEM. Pre, before exercise; Post, immediately after exercise; Recovery, $60 \mathrm{~min}$ after exercise. $†$ Significant difference between FW-T and CHO-T for boys and men, $p<0.05$.

leukocytes remained higher than resting values for both groups, but were lower $(p<0.001)$ in boys compared with men. At $1 \mathrm{~h}$ of recovery, leukocytes were lower $(p<0.001)$ during $\mathrm{CHO}-\mathrm{T}$, compared with FW-T in both groups. Lymphocytes increased after exercise $(p<0.001)$ during FW-T to a similar extent in both groups (Table 2). During recovery in both trials, lymphocytes were lower than resting values in men, but not in boys $(p<0.001)$. CHO ingestion had no significant effect on lymphocytes after exercise or during recovery. The pattern of change in monocytes was similar among groups and trials immediately after, and $1 \mathrm{~h}$ after exercise (Table 2). At all time points during FW-T and CHO-T, neutrophil concentrations (Table 2) were significantly higher in the men than in the boys $(p=0.01)$. In both groups, exercise induced a significant $(p<0.001)$ increase in neutrophils above resting values during FW-T. During CHO-T, exercise also increased neutrophil levels above resting in the men, but not in the boys. At $1 \mathrm{~h}$ after exercise in FW-T, neutrophils continued to increase in men ( $p$ $<0.05$ ) but remained constant in boys, compared with postexercise values. Compared with FW-T, neutrophils recovered close to resting values in CHO-T for both groups $(p<0.001)$.

Lymphocyte subsets. During both trials, the proportion of $\mathrm{T}$ cells remained constant in boys, but decreased in men immediately after exercise $(p<0.05$, Table 3$)$. The proportion of NK cells increased with exercise $(p<0.01)$ during FW-T in both groups, but to a smaller extent in boys than in men $(p<$ 0.001 , Table 3). CHO ingestion attenuated the increase in NK cell proportions in boys but not in men $(p<0.05)$. By $1 \mathrm{~h}$ after exercise, NK cell proportions were not different from resting values in both groups and trials. The proportion of NK T cells did not increase significantly in boys in either trial (Table 3). For men, the proportion of NK T cells increased above resting levels immediately after exercise during FW-T $(p<0.05)$, but not during CHO-T. By $1 \mathrm{~h}$ of recovery in both trials, the proportions of NK T cells were not different from rest in either group. Figure 2 shows the concentrations of T, NK, and NK T cells before, immediately after, and $1 \mathrm{~h}$ after exercise. Exercise caused an increase in T cell counts above resting values $(p<$
0.001) in both groups during FW-T, but not during CHO-T. Comparable to the lymphocyte response, men had a significant $(p=0.04)$ suppression of T cells during recovery, whereas boys recovered to resting values. NK cells significantly $(p<$ 0.001 ) increased above resting values in boys during FW-T, but not during CHO-T. In contrast, NK cells increased with exercise $(p<0.001)$ during FW-T and CHO-T to the same extent in men. NK cells were lower $(p<0.05)$ in boys than in men immediately after exercise in both trials, but recovered to a similar extent between groups and trials. NK T cell counts did not significantly change with exercise in boys, but increased above resting values with exercise $(p<0.05)$ during both trials in men. NK T cells were significantly $(p=0.01)$ lower in boys than in men immediately after exercise during FW-T only. By $1 \mathrm{~h}$ after exercise in both trials, NK T cells had recovered to resting values in both groups. The NK T cell population, regardless of group or trial, responded much less to exercise than the NK cell population.

Cytokines. Sufficient plasma for cytokine determination was available for nine boys and nine men only. This subset of subjects did not differ from the main group in any physical or exercise variable presented above. $\mathrm{CHO}$ intake had no effect on the cytokine response to exercise in either group, and the data from both beverage trials were therefore pooled. Resting concentrations of IL-6 (Fig. 3A) were significantly $(p<0.05)$ higher in the boys compared with the men. Exercise caused a significant $(p<0.05)$ increase in IL-6 in the men but not in the boys. In the men, IL- 6 remained elevated $(p<0.001)$ during recovery compared with pre-exercise values. In the boys, there was less than a $1 \mathrm{pg} / \mathrm{mL}$ change in IL-6 over time. Although TNF- $\alpha$ levels (Fig. $3 B$ ) were higher in the boys than in the men at each time point, these differences were not statistically significant. There was no significant effect of exercise on TNF- $\alpha$ levels in either group.

\section{DISCUSSION}

This study was designed to determine age-associated differences in the immune response to strenuous exercise with and without $\mathrm{CHO}$ intake, and is the first, to our knowledge, that directly compared children and adults under the same experimental conditions. Our data provide several novel findings with respect to the immediate response to exercise and the recovery of the immune system after exercise and can be summarized as follows: 1) the magnitude of the NK and NK T cell responses to exercise is considerably smaller in boys than in men; 2) boys do not experience a postexercise suppression of lymphocytes or $\mathrm{T}$ cells typically observed in adults; 3 ) the magnitude of the IL-6 response to exercise is smaller in boys than in men; and 4) $\mathrm{CHO}$ supplementation attenuated the immediate exercise-induced increase in some immune counts in boys, but not in men.

It is well recognized that NK cells are mobilized during exercise in response to an increase in epinephrine (5), due to a high surface density of $\beta$-adrenergic receptors (33). Indeed we chose to measure NK cells because they are the most responsive type of cell to exercise (6). Although we did not measure epinephrine, the smaller NK cell response in the boys would be 
Table 2. Total number of leukocytes, neutrophils, lymphocytes, and monocytes before, immediately after and $1 \mathrm{~h}$ after exercise in flavored water and carbohydrate trials for boys and men

\begin{tabular}{|c|c|c|c|c|c|c|}
\hline & \multicolumn{3}{|c|}{ FW-T } & \multicolumn{3}{|c|}{ CHO-T } \\
\hline & Pre & Post & Recovery & Pre & Post & Recovery \\
\hline \multicolumn{7}{|c|}{ Leukocytes } \\
\hline Men & $6.35 \pm 0.64$ & $8.79 \pm 0.72 \ddagger$ & $8.43 \pm 0.80 \%$ & $6.34 \pm 0.46$ & $8.51 \pm 0.64 \ddagger$ & $6.27 \pm 0.52 \dagger \S$ \\
\hline \multicolumn{7}{|c|}{ Neutrophils } \\
\hline Boys & $2.48 \pm 0.34 *$ & $3.49 \pm 0.41 *+$ & $3.59 \pm 0.53 *$ & $2.43 \pm 0.19 *$ & $3.01 \pm 0.25^{*}$ & $2.53 \pm 0.18 * \dagger$ \\
\hline Men & $3.67 \pm 0.61$ & $5.00 \pm 0.71 \dagger$ & $6.01 \pm 0.75 \$ \S$ & $3.48 \pm 0.44$ & $4.77 \pm 0.57 t$ & $3.98 \pm 0.46 \dagger$ \\
\hline Boys & $2.07 \pm 0.12$ & $2.71 \pm 0.17 \ddagger$ & $2.15 \pm 0.09 * \S$ & $2.06 \pm 0.14$ & $2.36 \pm 0.19$ & $2.08 \pm 0.15^{*}$ \\
\hline Men & $1.83 \pm 0.12$ & $2.63 \pm 0.19 \$$ & $1.53 \pm 0.10 \$ \S$ & $1.97 \pm 0.13$ & $2.51 \pm 0.25 t$ & $1.46 \pm 0.14 \div \S$ \\
\hline \multicolumn{7}{|c|}{ Monocytes } \\
\hline Boys & $0.37 \pm 0.03$ & $0.53 \pm 0.07 \$$ & $0.43 \pm 0.04$ & $0.36 \pm 0.02$ & $0.50 \pm 0.04 \leftrightarrows$ & $0.42 \pm 0.04$ \\
\hline Men & $0.50 \pm 0.04$ & $0.74 \pm 0.05 t$ & $0.58 \pm 0.05 \S$ & $0.51 \pm 0.04$ & $0.68 \pm 0.06 t$ & $0.53 \pm 0.04 \S$ \\
\hline
\end{tabular}

Values are means \pm SEM in $10^{9}$ cells/L. FW-T, flavored water trial; CHO-T, carbohydrate trial. Pre, before exercise; Post, immediately after exercise; Recovery, $60 \mathrm{~min}$ after exercise.

* Significantly different from men, $p<0.05$.

$\dagger$ Significantly different from FW-T, $p<0.05$.

$\ddagger$ Significantly different from Pre, $p<0.05$.

$\S$ Significantly different from Post, $p<0.05$.

Table 3. Relative proportions of lymphocyte subsets before, immediately after, and $1 \mathrm{~h}$ after exercise in flavored water and carbohydrate trials for boys and men

\begin{tabular}{|c|c|c|c|c|c|c|}
\hline & \multicolumn{3}{|c|}{ FW-T } & \multicolumn{3}{|c|}{ CHO-T } \\
\hline & Pre & Post & Recovery & Pre & Post & Recovery \\
\hline \multicolumn{7}{|l|}{$\mathrm{T}$ cells } \\
\hline Men & $69.9 \pm 2.7$ & $63.4 \pm 2.8 t$ & $66.5 \pm 4.3$ & $69.1 \pm 2.9$ & $63.3 \pm 3.2 \ddagger$ & $70.0 \pm 3.1 \S$ \\
\hline \multicolumn{7}{|l|}{ NK cells } \\
\hline Boys & $9.9 \pm 0.9$ & $15.6 \pm 1.8^{* t}$ & $10.2 \pm 1.4 \S$ & $10.2 \pm 0.9$ & $12.5 \pm 1.7 * \dagger$ & $8.0 \pm 0.9 \S$ \\
\hline Boys & $10.0 \pm 1.8$ & $10.2 \pm 1.6^{*}$ & $9.1 \pm 1.7$ & $10.9 \pm 2.6$ & $12.9 \pm 3.1$ & $8.7 \pm 1.3$ \\
\hline Men & $10.4 \pm 2.2$ & $16.3 \pm 3.6 t$ & $10.4 \pm 1.8 \S$ & $7.4 \pm 1.2$ & $12.8 \pm 3.0$ & $9.6 \pm 2.8$ \\
\hline
\end{tabular}

Values are means \pm SEM given in percentage. FW-T, flavored water trial; CHO-T, carbohydrate trial. Pre, before exercise; Post, immediately after exercise; Recovery, 60 min after exercise.

* Significantly different from men, $p<0.05$.

$\dagger$ Significantly different from FW-T, $p<0.05$.

$\$$ Significantly different from Pre, $p<0.05$.

$\S$ Significantly different from Post, $p<0.05$.

consistent with a smaller epinephrine response. Indirect evidence (30) suggests that children may have a lower epinephrine response to sustained exercise then adults, but we are unaware of any direct age comparison during prolonged exercise. Alternatively, the smaller NK cell response could be due to a lower density of $\beta$-adrenergic receptors on this cell type in boys, compared with men. This possibility is supported by previous work reporting a positive correlation between age and lymphocyte $\beta$-adrenergic receptor density (34). Regardless of the mechanism(s), the attenuated NK cell response in the boys, compared with the men, is a novel finding and requires further investigation.

Another novel aspect of the present study is the NK T cell response to exercise in children. In adults, resting concentrations of NK T cells $\left(\mathrm{CD}^{+} \mathrm{CD} 16^{+} \mathrm{CD} 56^{+}\right)$cells seem to constitute a relatively small $(<6 \%)$ proportion of peripheral blood lymphocytes $(35,36)$. The proportion of NK T cells measured in the present study $(\sim 10 \%)$ is slightly higher than in these previous studies, but had a distinct response to exercise, which was con- siderably smaller than that recorded for NK cells in both age groups. Interestingly, Søndergaard et al. (37) reported a smaller increase in NK T cells $\left(\mathrm{CD} 3^{+} \mathrm{CD} 16^{+} \mathrm{CD} 56^{+}\right)$, compared with NK cells $\left(\mathrm{CD}^{-} \mathrm{CD} 16^{+} \mathrm{CD} 56^{+}\right)$, in response to epinephrine infusion in healthy young adults, which suggests that the NK T cell population may also have a distinct response to exercise, a hypothesis that our results corroborate. Furthermore, the magnitude of the NK T cell response was also considerably smaller in the boys than in the men regardless of trial.

Taken together, these results suggest that, compared with adults, some components of the innate immune system in children are less responsive to physiologic stress. However, the functional significance of this finding remains to be determined. NK cells are an important first line of defense against viruses and tumor growth $(38,39)$. NK T cells, although considered components of the innate immune system, appear to facilitate and direct adaptive immune responses $(40,41)$. NK and NK T cells may, therefore, play important roles in the proposed relationship between improved resistance to infection 

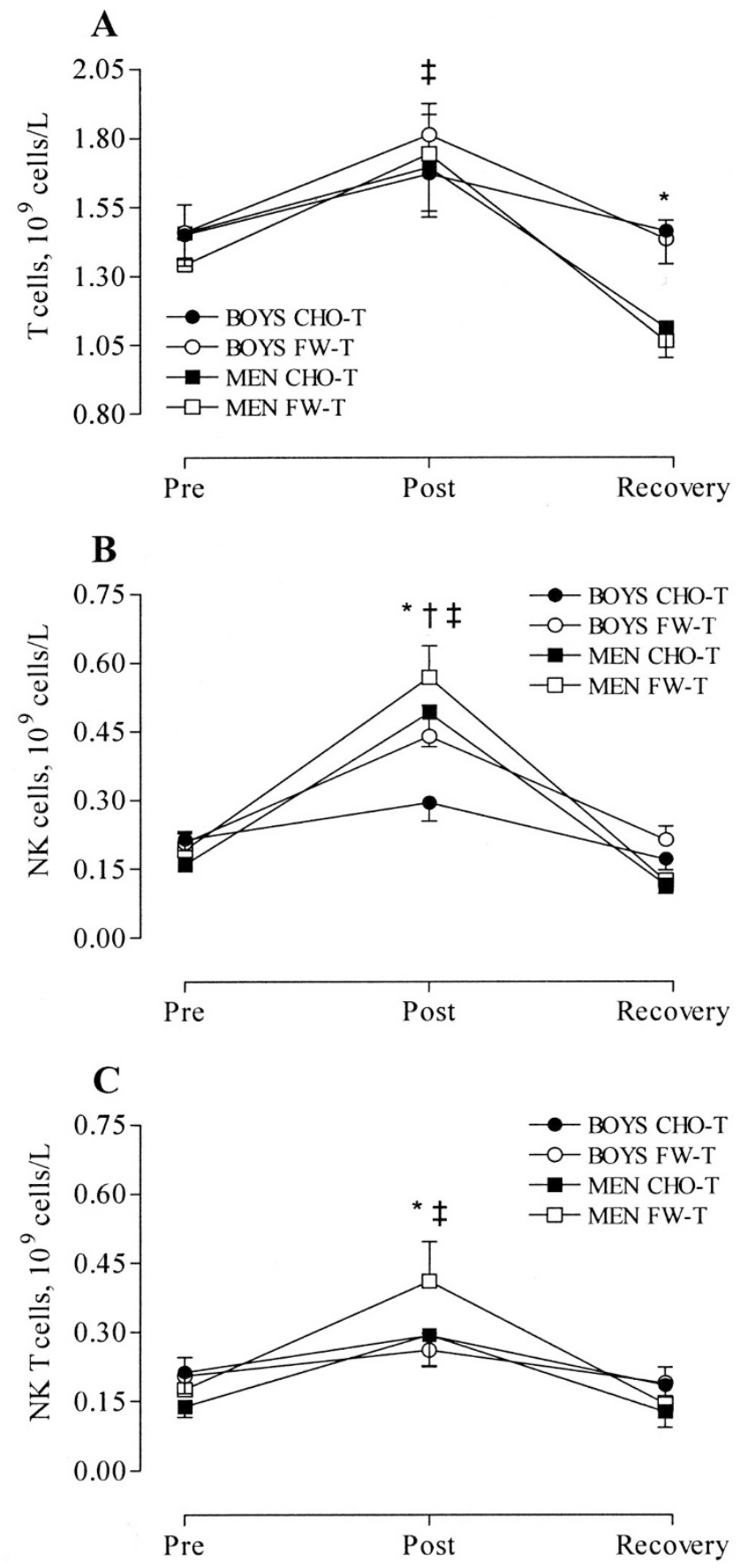

Figure 2. Blood concentrations of T cells $(A)$, NK cells $(B)$, and NK T cells $(C)$ before, immediately after, and $1 \mathrm{~h}$ after exercise in flavored water and carbohydrate trials for boys and men. Values are means \pm SEM. Pre, before exercise; Post, immediately after exercise; Recovery, $60 \mathrm{~min}$ after exercise. *Significant difference between boys and men, $p<0.05$. $\uparrow$ Significant difference between FW-T and CHO-T, $p<0.05$. $\vdots$ Significantly different from Pre, $p<0.05$. See "Results" for details of comparisons.

(e.g. respiratory infections) and regular physical activity (42). However, more research is clearly needed to describe the relationship between physical activity level and immune function in growing children.

Another main finding in the present study was the lack of postexercise suppression in the lymphocyte and T-cell populations in the boys. This apparent faster recovery of lymphoid

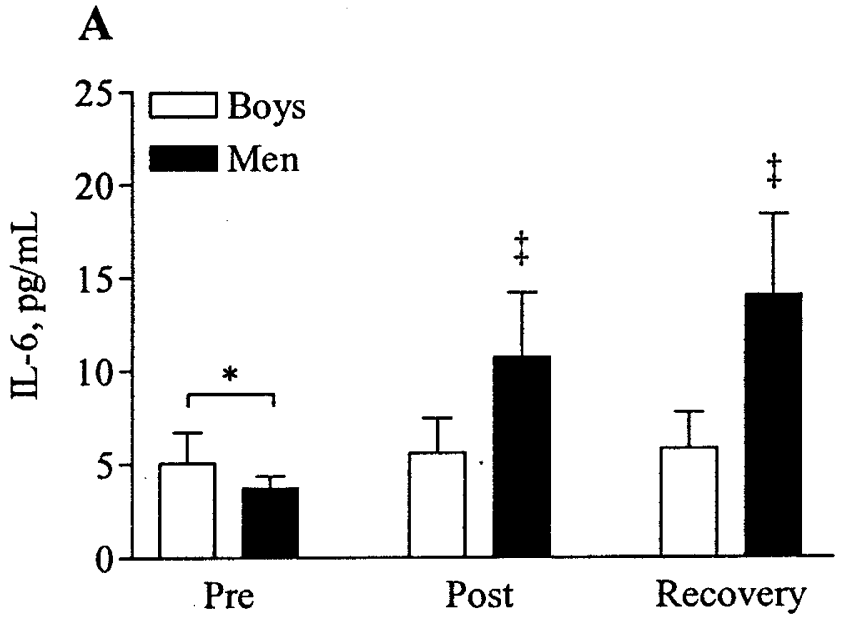

\section{B}

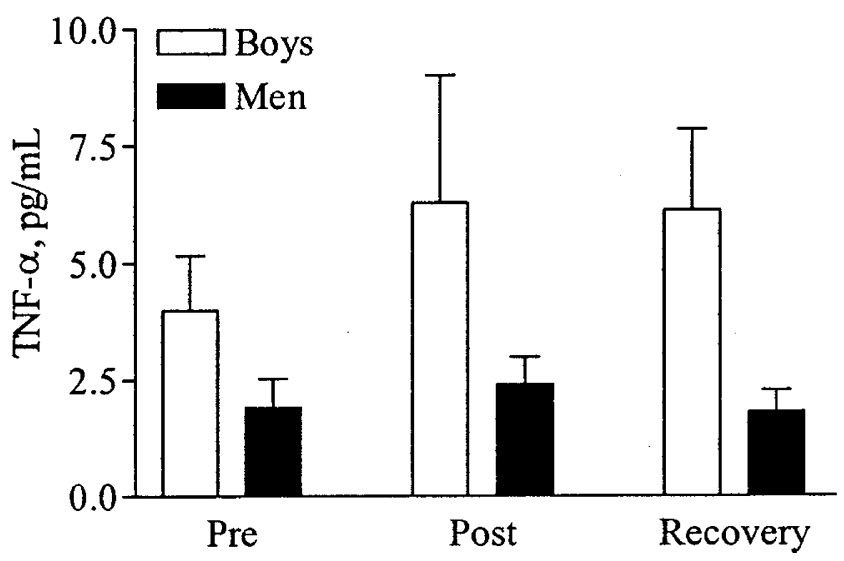

Figure 3. Plasma IL-6 $(A)$ and TNF- $\alpha(B)$ concentrations before, immediately after, and $1 \mathrm{~h}$ after exercise in flavored water and carbohydrate trials for boys $(n=9)$ and men $(n=9)$. Values are mean \pm SEM. Pre, before exercise; Post, immediately after exercise; Recovery, $60 \mathrm{~min}$ after exercise. *Significant difference between boys and men, $p<0.05$; $\ddagger$ Significantly different from Pre, $p<0.05$.

cells supports our original hypothesis and is consistent with the notion that recovery from exercise tends to be faster in children, compared with adults. Postexercise lymphopenia is a classical response to high-intensity ( $\left.\geq 75 \% \dot{\mathrm{V}}_{\mathrm{O}_{2 \max }}\right)$ exercise in adults (43) and is likely mediated by a prolonged elevation of cortisol (6). The lack of a postexercise suppression in lymphoid cells implies that boys do not experience an "open window" period as proposed for adult men. However, interpretation of an absent postexercise lymphopenia in the boys is complicated by a lack of multiple sampling points during recovery. It is possible that we simply missed any suppression either before or after the 60 -min sampling time. Although we cannot completely discount this possibility, it is noteworthy that Shore and Shephard (16) did not find suppression of lymphocytes or $\mathrm{T}$ cells in their children $30 \mathrm{~min}$ after a $30-\mathrm{min}$ bout of exercise performed at an intensity corresponding to their ventilatory threshold. Even if suppression occurred earlier (i.e. at $30 \mathrm{~min}$ postexercise) in the current study, the finding that lymphocytes had returned to resting levels in the boys, but not in the men, by $60 \mathrm{~min}$ postexercise adds to the notion that children recover from exercise more quickly than adults, and 
our data add to this phenomenon in terms of the immune system. Another limitation in our study is that we did not measure immune function per se, but rather changes in the number and proportion of various immune cells, thereby restricting conclusions pertaining to clinical significance. There has been considerable debate over whether exercise alters, for example, intrinsic NK cell cytotoxicity (44) and lymphocyte proliferation (45) or whether these changes in immune function simply reflect alterations in cell numbers. Unfortunately, we cannot add to this debate in a meaningful way with the present results, but studies are now underway in our laboratory to pursue this issue.

As regards cytokines, it is well established that strenuous exercise is a powerful stimulus to increase levels of various cytokines in the peripheral circulation $(9,46)$. The magnitude of increase in IL-6 after exercise is typically intensity dependent (47). In contrast, TNF- $\alpha$ generally increases only with high-intensity, long-duration exercise involving a large muscle mass (48). Therefore, it was not surprising that, after exercise in the current study, IL-6 increased without changes in TNF- $\alpha$ levels in the men (Fig. 3), inasmuch as this pattern has been shown previously in adult men (49). In the present study, absolute changes in the concentration of IL-6 $(\sim 0.6 \mathrm{pg} / \mathrm{mL})$ and TNF- $\alpha(\sim 2.3 \mathrm{pg} / \mathrm{mL})$ after exercise were small in the boys and did not achieve statistical significance. Scheet et al. (50) and Tirakitsoontorn et al. (51) reported similarly small absolute changes for IL-6 $(\sim 1.55 \mathrm{pg} / \mathrm{mL}$ and $\sim 1.0 \mathrm{pg} / \mathrm{mL}$, respectively) and TNF- $\alpha(\sim 0.4 \mathrm{pg} / \mathrm{mL}$ and $\sim 0.3 \mathrm{pg} / \mathrm{mL}$, respectively) after exercise in healthy children, which did reach statistical significance. An obvious question, therefore, is whether small changes in IL-6 and TNF- $\alpha$, which may or may not reach statistical significance, are of biologic significance.

Scheet et al. (50) proposed that exercise-induced increases in the inflammatory cytokines IL- 6 and TNF- $\alpha$ may inhibit growth mediators (e.g. IGF-1) resulting in a catabolic environment such as is seen in other catabolic states (e.g. trauma, burns, and sepsis). In their study, a "real-life" soccer practice of moderate intensity with rest periods was used as the exercise stimulus, with apparently no control over fluid intake or previous diet and exercise. In contrast, we used an exercise model of high-intensity, prolonged cycling to impart significant stress on the immune system. With this approach, and under wellcontrolled study conditions, we still found only minor changes in IL-6 and TNF- $\alpha$. It would therefore appear that young children are relatively resistant to a major inflammatory response to acute exercise and, thus, a catabolic state. However, since we did not measure circulating growth mediators (e.g. IGF-1), we cannot completely dismiss a catabolic response (e.g. a decrease in IGF-1 levels).

To our knowledge, this is the first study to investigate the effects of $\mathrm{CHO}$ intake on changes in immune cell counts after exercise in young (i.e. pre- and early pubertal) children. Although exercise performed without $\mathrm{CHO}$ intake caused significant increases in the concentration of neutrophils, lymphocytes, T cells, and NK cells in the boys, there was no change in the concentration of these cells from resting values after exercise in the trial with $\mathrm{CHO}$ intake. Interestingly, in the men, only the proportion of NK T cells and T-cell counts did not change from resting values during CHO-T. During recovery, leukocyte and neutrophil counts were lower during CHO-T than FW-T in both groups. The apparent age-related difference in sensitivity of immune cells to $\mathrm{CHO}$ intake may be related to an age-related difference in the sensitivity of the stress hormone (e.g. epinephrine and cortisol) response to $\mathrm{CHO}$ intake during exercise. Taken together, our results imply that, with acute $\mathrm{CHO}$ supplementation, overall physiologic stress is diminished, and studies are now underway in our laboratory to clarify possible growth-related changes in hormone-immune interactions during exercise in healthy children. The potential clinical significance of nutritional strategies such as $\mathrm{CHO}$ intake during exercise on immune function in children recovering from disease, for example, awaits further study.

In summary, $60 \mathrm{~min}$ of exercise, performed at a similar relative intensity, caused significantly smaller increases in total leukocytes, NK cells, NK T cells, and IL-6 in pre- and early pubertal boys than in young adult men. The well-described postexercise lymphopenia after high-intensity exercise, which occurs in adults, was not identified in our boys. Exerciseinduced changes in some elements of the immune system were more sensitive to $\mathrm{CHO}$ ingestion in the boys than in the men. Our results provide, for the first time, strong evidence that the magnitude and direction of exercise-induced changes in cellular components of the human immune system may be influenced by the age or maturity status of an individual. As such, this preliminary information should be considered when interpreting "normal" leukocyte kinetics in response to exercise in children with, or recovering from, an immune-related disease.

Acknowledgments. The authors thank Marta Kubacki for assistance with this experiment, and our subjects for their time and effort. We also thank Dr. Craig Horswill for valuable comments on an earlier version of this manuscript.

\section{REFERENCES}

1. Nieman DC, Miller AR, Henson DA, Warren BJ, Gusewitch G, Johnson RL, Davis JM, Butterworth DE, Herring JL, Nehlsen-Cannarella SL 1994 Effect of high- versus moderate-intensity exercise on lymphocyte subpopulations and proliferative response. Int J Sports Med 15:199-206

2. Tvede N, Kappel M, Halkjaer-Kristensen J, Galbo H, Pedersen BK 1993 The effect of light, moderate and severe bicycle exercise on lymphocyte subsets, natural and lymphokine activated killer cells, lymphocyte proliferative response and interleukin 2 production. Int J Sports Med 14:275-282

3. Gleeson M, Blannin AK, Walsh NP, Bishop NC, Clark AM 1998 Effect of low- and high-carbohydrate diets on plasma glutamine and circulating leukocyte responses to exercise. Int J Sport Nutr 8:49-59

4. Mitchell JB, Pizza FX, Paquet A, Davis BJ, Forrest MB, Braun WA 1998 Influence of carbohydrate status on immune responses before and after endurance exercise. J Appl Physiol 84:1917-1925

5. Tvede N, Kappel M, Klarlund K, Duhn S, Halkjaer-Kristensen J, Kjaer M, Galbo H, Pedersen BK 1994 Evidence that the effect of bicycle exercise on blood mononuclear cell proliferative responses and subsets is mediated by epinephrine. Int J Sports Med 15:100-104

6. Pedersen BK, Hoffman-Goetz L 2000 Exercise and the immune system: regulation, integration, and adaptation. Physiol Rev 80:1055-1081

7. Pedersen BK, Ullum H 1994 NK cell response to physical activity: possible mechanisms of action. Med Sci Sports Exerc 26:140-146

8. Balkwill F 2001 Cytokines and cytokine receptors. In: Roitt I, Brostoff J, Male D (eds) Immunology. Harcourt Publishers Ltd., London, pp 119-129

9. Rhind SG, Shek PN, Shepard RJ 1995 The impact of exercise on cytokines and receptor expression. Exerc Immunol Rev 1:97-148

10. Starkie RL, Angus DJ, Rolland J, Hargreaves M, Febbraio MA 2000 Effect of prolonged, submaximal exercise and carbohydrate ingestion on monocyte intracellular cytokine production in humans. J Physiol 528:647-655

11. Starkie RL, Rolland J, Febbraio MA 2001 Effect of adrenergic blockade on lymphocyte cytokine production at rest and during exercise. Am J Physiol Cell Physiol 281:C1233-C1240 
12. Starkie RL, Rolland J, Angus DJ, Andersen MJ, Febbraio MA 2001 Circulating monocytes are not the source of elevations in plasma IL-6 and TNF- $\alpha$ levels after prolonged running. Am J Physiol Cell Physiol 280:C769-C774

13. Vassilakopoulos T, Karatza MH, Katsaounou P, Kollintza A, Zakynthinos S, Roussos C 2003 Antioxidants attenuate the plasma cytokine response to exercise in humans. J Appl Physiol 94:1025-1032

14. Eliakim A, Wolach B, Kodesh E, Gavrieli R, Radnay J, Ben Tovim T, Yarom Y, Falk B 1997 Cellular and humoral immune response to exercise among gymnasts and untrained girls. Int J Sports Med 18:208-212

15. Perez CJ, Nemet D, Mills PJ, Scheet TP, Ziegler MG, Cooper DM 2001 Effects of laboratory versus field exercise on leukocyte subsets and cell adhesion molecule expression in children. Eur J Appl Physiol 86:34-39

16. Shore S, Shepard RJ 1998 Immune responses to exercise and training: a comparison of children and young adults. Pediatr Exerc Sci 10:210-226

17. Soares JM, Mota P, Duarte JA, Appell HJ 1996 Children are less susceptible to exercise-induced muscle damage than adults: a preliminary investigation. Pediatr Exerc Sci 8:361-367

18. Webber LM, Byrnes WC, Rowland TW, Foster VL 1989 Serum creatine kinase and delayed onset muscle soreness in prepubescent children: a preliminary study. Pediatr Exerc Sci 1:351-359

19. Bar-Or O 1983 Pediatric Sports Medicine for the Practitioner: From Physiological Principles to Clinical Applications. Springer-Verlag, Berlin, p 1

20. Nieman DC, Pedersen BK 2000 Nutrition and Exercise Immunology. CRC Press, Boca Raton, FL

21. Bishop NC, Gleeson M, Nicholas CW, Ali A 2002 Influence of carbohydrate supplementation on plasma cytokine and neutrophil degranulation response to high intensity intermittent exercise. Int J Sport Nutr Exerc Metab 12:145-156

22. Nieman DC, Nehlsen-Cannarella SL, Fagoaga OR, Henson DA, Utter A, Davis JM, Williams F, Butterworth DE 1998 Effects of mode and carbohydrate on the granulocyte and monocyte response to intensive, prolonged exercise. J Appl Physio $84: 1252-1259$

23. Henson DA, Nieman DC, Blodgett AD, Butterworth DE, Utter A, Davis JM, Sonnenfeld G, Morton DS, Fagoaga OR, Nehlsen-Cannarella SL 1999 Influence of exercise mode and carbohydrate on the immune response to prolonged exercise. Int J Sport Nutr 9:213-228

24. Nieman DC, Henson DA, Garner EB, Butterworth DE, Warren BJ, Utter A, Davis JM, Fagoaga OR, Nehlsen-Cannarella SL 1997 Carbohydrate affects natural killer cell redistribution but not activity after running. Med Sci Sports Exerc 29:1318-1324

25. Starkie RL, Arkinstall MJ, Koukoulas I, Hawley JA, Febbraio MA 2001 Carbohydrate ingestion attenuates the increase in plasma interleukin-6, but not skeletal muscle interleukin-6 mRNA, during exercise in humans. J Physiol 533:585-591

26. Febbraio MA, Steensberg A, Keller C, Starkie RL, Nielsen HB, Krustrup P, Ott P, Secher NH, Pedersen BK 2003 Glucose ingestion attenuates interleukin-6 release from contracting skeletal muscle in humans. J Physiol 549:607-612

27. Nieman DC, Davis JM, Henson DA, Walberg-Rankin J, Shute M, Dumke CL, Utte AC, Vinci DM, Carson JA, Brown A, Lee WJ, McAnulty SR, McAnulty LS 2003 Carbohydrate ingestion influences skeletal muscle cytokine mRNA and plasma cytokine levels after a 3-h run. J Appl Physiol 94:1917-1925

28. Nieman DC, Nehlsen-Cannarella SL, Fagoaga OR, Henson DA, Utter A, Davis JM, Williams F, Butterworth DE 1998 Influence of mode and carbohydrate on the cytokine response to heavy exertion. Med Sci Sports Exerc 30:671-678

29. Nieman DC 1998 Influence of carbohydrate on the immune response to intensive, prolonged exercise. Exerc Immunol Rev 4:64-76

30. Rowland TW 1996 Developmental Exercise Physiology. Human Kinetics, Champaign, IL, p 236
31. Tanner JM 1962 Growth at Adolescence. Blackwell Scientific, Oxford, UK, pp 32-37

32. Dill DB, Costill DL 1974 Calculation of percentage changes in volumes of blood, plasma, and red cells in dehydration. J Appl Physiol 37:247-248

33. Landmann R 1992 Beta-adrenergic receptors in human leukocyte subpopulations. Eur J Clin Invest 22(suppl 1):30-36

34. Reinhardt D, Zehmisch T, Becker B, Nagel-Hiemke M 1984 Age-dependency of alpha- and beta-adrenoceptors on thrombocytes and lymphocytes of asthmatic and nonasthmatic children. Eur J Pediatr 142:111-116

35. Ortaldo JR, Winkler-Pickett RT, Yagita H, Young HA 1991 Comparative studies of $\mathrm{CD}^{-}$and $\mathrm{CD}^{+}{ }^{+} \mathrm{CD} 56^{+}$cells: examination of morphology, functions, $\mathrm{T}$ cell receptor rearrangement, and pore-forming protein expression. Cell Immunol 136:486-495

36. Theilgaard-Monch K, Raaschou-Jensen K, Palm H, Schjodt K, Heilmann C, Vindelov L, Jacobsen N, Dickmeiss E 2001 Flow cytometric assessment of lymphocyte subsets, lymphoid progenitors, and hematopoietic stem cells in allogeneic stem cell grafts. Bone Marrow Transplant 28:1073-1082

37. Søndergaard SR, Ullum H, Skinhoj P, Pedersen BK 1999 Epinephrine-induced mobilization of natural killer (NK) cells and NK-like T cells in HIV-infected patients. Cell Immunol 197:91-98

38. Herberman RB, Ortaldo JR 1981 Natural killer cells: their role in defenses against disease. Science 214:24-30

39. Biron CA, Nguyen KB, Pien GC, Cousens LP, Salazar-Mather TP 1999 Natural killer cells in antiviral defense: function and regulation by innate cytokines. Ann Rev Immunol 17:189-220

40. Carnaud C, Lee D, Donnars O, Park SH, Beavis A, Koezuka Y, Bendelac A 1999 Cutting edge: cross-talk between cells of the innate immune system: NKT cells rapidly activate NK cells. J Immunol 163:4647-4650

41. Peritt D, Robertson S, Gri G, Showe L, Aste-Amezaga M, Trinchieri G 1998 Differentiation of human NK cells into NK1 and NK2 subsets. J Immunol 161:58215824 .

42. Nieman DC 1997 Exercise immunology: practical applications. Int J Sports Med 18:S91-S100

43. Pedersen BK, Rohde T, Ostrowski K 1998 Recovery of the immune system after exercise. Acta Physiol Scand 162:325-332

44. Gannon GA, Shek P, Shepard RJ 1995 Natural killer cells: modulation by intensity and duration of exercise. Exerc Immunol Rev 1:26-48

45. Nielsen HB, Pedersen BK 1997 Lymphocyte proliferation in response to exercise. Eur J Appl Physiol Occup Physiol 75:375-379

46. Suzuki K, Nakaji S, Yamada M, Totsuka M, Sato K, Sugawara K 2002 Systemic inflammatory response to exhaustive exercise. Cytokine kinetics. Exerc Immunol Rev $8: 6-48$

47. Ostrowski K, Schjerling P, Pedersen BK 2000 Physical activity and plasma interleukin-6 in humans-effect of intensity of exercise. Eur J Appl Physiol 83:512-515

48. Brenner IK, Natale VM, Vasiliou P, Moldoveanu AI, Shek PN, Shephard RJ 1999 Impact of three different types of exercise on components of the inflammatory response. Eur J Appl Physiol Occup Physiol 80:452-460

49. Steensberg A, Keller C, Starkie RL, Osada T, Febbraio MA, Pedersen BK 2002 IL-6 and TNF-alpha expression in, and release from, contracting human skeletal muscle. Am J Physiol Endocrinol Metab 283:E1272-E1278

50. Scheett TP, Mills PJ, Ziegler MG, Stoppani J, Cooper DM 1999 Effect of exercise on cytokines and growth mediators in prepubertal children. Pediatr Res 46:429-434

51. Tirakitsoontorn P, Nussbaum E, Moser C, Hill M, Cooper DM 2001 Fitness, acute exercise, and anabolic and catabolic mediators in cystic fibrosis. Am J Respir Crit Care Med 164:1432-1437 